\title{
Evaluation of Serum Level of Glutathione Peroxidase Activity in Vitiligo Patients
}

\author{
AYA E. ARAFAT, M.Sc.*; ENGI S.E. SHAKER, M.D.*; MAALY M. MABROUK, M.D.** and \\ MOHAMMAD M. GAMEE, M.D. * \\ The Departments of Dermatology \& Venereology* and Clinical Pathology**, Faculty of Medicine, Tanta University, \\ Tanta, Egypt
}

\begin{abstract}
Background: Vitiligo is an acquired disorder with loss of epidermal melanocytes. Oxidative stress is thought to play a significant role in the pathogenesis of vitiligo. Glutathione Peroxidase $(\mathrm{GPx})$ is one of the most important antioxidant enzymes.

Aim of Study: To estimate serum levels of Glutathione Peroxidase activity in patients with vitiligo to assess its role in the disease activity.

Patients and Methods: This study included (60) patients with vitiligo and (20) healthy individuals served as a control group. They were collected from the Outpatient Clinic of Dermatology and Venereology Department Tanta University Hospital. Serum levels of glutathione peroxidase activity were estimated in the patients and control group.

Results: Serum GPx activity level showed a statistically significant increase in vitiligo patients compared to control group.

Conclusion: Oxidative stress is thought to play a significant role in the pathogenesis of vitiligo represented by significantly increased GPx activity level in vitiligo patients.
\end{abstract}

Key Words: Vitiligo-Glutathione peroxidase.

\section{Introduction}

VITILIGO is an acquired disease with circumscribed depigmented macules and patches due to loss of functioning melanocytes. Vitiligo may develop anywhere on the body [1]. Sites that are normally relatively hyperpigmented such as the face, dorsal aspect of the hands, axillae, umbilicus, nipples, sacral, inguinal and anogenital regions are the common regions. The incidence is $0.1 \%$ to $2.0 \%$ worldwide [2].

Correspondence to: Dr. Aya El-Sayed Arafat, E-Mail: ayaarafat22@yahoo.com.
There are two types of vitiligo: The first is Segmental Vitiligo (SV) and the second is NonSegmental vitiligo (NSV). Non-segmental vitiligo is classified into (generalized, universal, focal, acrofacial, and mucosal vitiligo). Both sexes may be affected. In vitiligo, there is absence of melanocytes in the skin lesion due to its destruction [3].

Vitiligo is a complex phenomenon in which genetic and non-genetic factors are encountered. In vitiligenous skin, there is no functional melanocytes.Destruction of melanocytes leads to loss of histochemically recognizable melanocytes [1]

Oxidative stress has an important factor in the pathogenesis of vitiligo, according to the selfdestructive theory of melanocytes in the pathogenesis of vitiligo [4]. During several physiological and pathological processes, there is production of several free radicals like Reactive Oxygen Species (ROS), superoxide anion $\left(\mathrm{O}_{2}^{-}\right)$, hydrogen peroxide $\left(\mathrm{H}_{2} \mathrm{O}_{2}\right)$, and nitric oxide [5]. These free radicals are scavenged by antioxidant enzymes and nonenzymatic antioxidants constantly. Antioxidant enzymes such as Superoxide Dismutase (SOD), Glutathione Peroxidase (GPx), Glutathione reductase, and Catalase (CAT), and non-enzymatic antioxidant as Beta-carotene, Vitamin C, and Vitamin E. In oxidative stress, antioxidant activity is decreased leading to increase in free radicals, which destroy cellular compounds like protein, carbohydrate, DNA, and lipids [6].

Glutathione Peroxidase (GPx) is a family of enzymes which has peroxidase activity. Its main action is to defend cells from oxidative injury by reducing free $\mathrm{H}_{2} \mathrm{O}_{2}$ to $\mathrm{H}_{2} \mathrm{O}$ and reducing lipid hydroperoxides to their corresponding alcohols [7] 
In humans, there are 8 identified isoforms of glutathione peroxidase (GPx1-8). GPx1, GPx3, and GPx4 are the most well described [8].

GPx-1 is an antioxidant enzyme which is the most plentiful in human tissues as it is found in the cytosol of most cells including RBCs. GPx1 is counteracting oxidative stress enzyme as it is the principal enzyme that decreases $\mathrm{H}_{2} \mathrm{O}_{2}$ and other hydroperoxides in cytosol and mitochondria [9] .

GPx-3, known as plasma glutathione peroxidase (GPx-P) or extracellular glutathione, occurs in the plasma as a glycoprotein and is considered the most useful extracellular antioxidant enzyme [9] .

Membrane-bound glutathione peroxidase GPX4 (phospholipids hydroperoxide GPx) decreases esterified lipids as it has the ability to decrease lipid-hydroperoxides inside biological membranes [9].

\section{Patients and Methods}

\section{Patients:}

This study included (60) patients with Vitiligo collected from the Outpatient Clinic of Dermatology and Venereology Department Tanta University Hospital (from February 2017 to February 2018). They were assessed according to VASI and VIDA scores. In addition to, (20) healthy individuals with matched age and sex served as a control group.

The study was approved by Research Ethics Committee at Faculty of Medicine, Tanta University, approval code (31373/02/17).

\section{Inclusion criteria:}

1- Newly diagnosed cases with Vitiligo.

2- Cases previously diagnosed and treated but stopped treatment for 3 months before enrollment in this study.

\section{Exclusion criteria:}

1- Patients under treatment (systemic, topical or phototherapy).

2- Patients who have systemic diseases (DM, thyroid disease, autoimmune disorders).

3- Patients who have a concomitant dermatological disease.

4- Pregnancy and lactation.

5- Obesity and BMI more than thirty.

6- Patients receiving drugs affecting lipid values.
Method:

All studied individuals were subjected to:

1- Complete history taking.

2- General and dermatological examination to exclude any systemic or dermatological diseases.

3- Ocular and audiological examination to exclude any associations with vitiligo.

4- Wood's lamp examination.

5- VASI and VIDA scores were assessed.

6- Photographs to the affected sites.

7- Written informed consent was taken before starting.

Sampling:

Seven $\mathrm{ml}$ of venous blood was withdrawn from each subject after fasting 10-12 hours. Two ml was delivered to EDTA tube for complete blood picture. The remaining blood was delivered to a plain tube and centrifuged. The serum was separated and divided into two aliquots. One aliquot used to determine liver, renal functions, glucose level and lipid profile at once. The remaining aliquot was stored at $20^{\circ} \mathrm{C}$ until assay of glutathione peroxidase activity level.

Serum level of Glutathione Peroxidase activity level (GPx) by Enzyme-Linked Immunosorbent Assay method.

\section{Results}

This study included 60 patients with vitiligo and 20 healthy persons with matched age and sex served as control group. Patients' demographic data, vitiligo type, duration of the disease, family history, activity, Vitiligo Area Severity Index (VASI) and Vitiligo Disease Activity Score (VIDA) discussed in (Tables 1,2).

Serum GPx activity level showed a statistically significant increase in vitiligo patients compared to control group $(p<0.001)$ group (Table 3$)$ and Graph (1). While the difference between segmental and nonsegmental groups was statistically nonsignificant.

In both segmental and non-segmental groups, the difference between serum activity level of GPx in active and stable cases was statistically nonsignificant group (Table 5) and Graph (2).

The correlations between serum activity level of GPx and clinical data including (activity, age, sex, duration, VASI and VIDA) in each group were statistically non-significant (Table 4). 
Table (1): Patients' demographic data.

\begin{tabular}{|c|c|c|c|c|c|c|}
\hline & \multicolumn{2}{|c|}{ Cases $(n=60)$} & \multicolumn{2}{|c|}{ Cases $(n=20)$} & \multirow{2}{*}{$\begin{array}{l}\text { Test } \\
\text { of sig. }\end{array}$} & \multirow{2}{*}{$p$} \\
\hline & No. & $\%$ & No. & $\%$ & & \\
\hline \multicolumn{7}{|l|}{ Sex: } \\
\hline Male & 18 & 30.0 & 8 & 40.0 & $\chi^{2}=$ & \multirow[t]{2}{*}{0.408} \\
\hline Female & 42 & 70.0 & 12 & 60.0 & 0.684 & \\
\hline \multicolumn{7}{|l|}{ Age (years): } \\
\hline Min.-max. & \multicolumn{2}{|c|}{$7.0-60.0$} & \multicolumn{2}{|c|}{$10.0-60.0$} & $\mathrm{U}=$ & \multirow[t]{3}{*}{0.718} \\
\hline Mean \pm SD & \multicolumn{2}{|c|}{$29.95 \pm 14.45$} & \multicolumn{2}{|c|}{$29.35 \pm 16.94$} & 567.50 & \\
\hline Median & \multicolumn{2}{|c|}{27.50} & \multicolumn{2}{|l|}{26.0} & & \\
\hline \multicolumn{7}{|l|}{$B M I\left(k g / m^{2}\right):$} \\
\hline Min.-max. & \multicolumn{2}{|c|}{$19.20-29.10$} & \multicolumn{2}{|c|}{$19.80-29.10$} & $t=$ & \multirow[t]{3}{*}{0.560} \\
\hline Mean \pm SD & \multirow{2}{*}{\multicolumn{2}{|c|}{$\begin{array}{l}24.60 \pm 2.79 \\
25.40\end{array}$}} & \multicolumn{2}{|c|}{$24.17 \pm 2.87$} & 0.586 & \\
\hline Median & & & \multicolumn{2}{|c|}{24.95} & & \\
\hline \multicolumn{7}{|c|}{$\begin{array}{l}p: \chi^{2} \text { and } p \text {-values for Chi square test for comparing between the } \\
\text { two groups. }\end{array}$} \\
\hline \multicolumn{7}{|c|}{$\begin{array}{l}\mathrm{U}, p: \mathrm{U} \text { and } p \text {-values for Mann Whitney test for comparing between } \\
\text { the two groups. }\end{array}$} \\
\hline \multicolumn{7}{|c|}{$\begin{aligned} t, p: t \text { and } p \text {-values for student } t \text {-test for comparing between the two } \\
\text { groups. }\end{aligned}$} \\
\hline
\end{tabular}

Table (2): Patients' data.

\begin{tabular}{|c|c|c|c|c|}
\hline Vitiligo type & \multicolumn{2}{|r|}{ No. } & \multicolumn{2}{|r|}{$\%$} \\
\hline Segmental & \multicolumn{2}{|r|}{15} & \multicolumn{2}{|c|}{25.0} \\
\hline Non-segmental & \multicolumn{2}{|r|}{45} & \multicolumn{2}{|c|}{75.0} \\
\hline • Generalized & \multicolumn{2}{|r|}{20} & \multicolumn{2}{|c|}{33.3} \\
\hline • Localized & \multicolumn{2}{|r|}{10} & \multicolumn{2}{|r|}{16.7} \\
\hline - Acrofacial & \multicolumn{2}{|r|}{9} & \multicolumn{2}{|r|}{15.0} \\
\hline \multirow[t]{3}{*}{ - Acral } & \multicolumn{2}{|r|}{6} & \multicolumn{2}{|r|}{10.0} \\
\hline & \multicolumn{2}{|c|}{$\begin{array}{l}\text { Segmental } \\
(\mathrm{n}=15)\end{array}$} & \multicolumn{2}{|c|}{$\begin{array}{l}\text { Non-segmental } \\
(\mathrm{n}=45)\end{array}$} \\
\hline & No. & $\%$ & No. & $\%$ \\
\hline Duration (years): & & & 31 & 68.9 \\
\hline$<5$ & 10 & 66.7 & 14 & 31.1 \\
\hline$\geq 5$ & 5 & 33.3 & 0.08 & 2.0 \\
\hline Min.-max. & \multicolumn{2}{|c|}{$0.13-22.0$} & \multicolumn{2}{|c|}{$4.04 \pm 6.07$} \\
\hline Mean $\pm \mathrm{SD}$ & \multicolumn{2}{|c|}{$5.67 \pm 8.67$} & \multicolumn{2}{|c|}{1.50} \\
\hline Median & \multicolumn{2}{|c|}{1.0} & & \\
\hline \multicolumn{5}{|l|}{ Family history: } \\
\hline Negative & 13 & 86.7 & 29 & 64.4 \\
\hline Positive & 2 & 13.3 & 16 & 35.6 \\
\hline \multicolumn{5}{|l|}{ Activity: } \\
\hline Active & 11 & 73.3 & 32 & 71.1 \\
\hline Stable & 4 & 26.7 & 13 & 28.9 \\
\hline \multicolumn{5}{|l|}{ VASI $(\%):$} \\
\hline Min.-max. & \multicolumn{2}{|c|}{$10.0-30.0$} & \multicolumn{2}{|c|}{$10.0-90.0$} \\
\hline Mean \pm SD. & \multicolumn{2}{|c|}{$20.67 \pm 6.23$} & \multicolumn{2}{|c|}{$32.22 \pm 22.55$} \\
\hline Median & \multicolumn{2}{|c|}{20.0} & \multicolumn{2}{|c|}{20.0} \\
\hline VIDA: & & & & \\
\hline Min.-max. & $0.0-$ & & $0.0-4$ & \\
\hline Mean $\pm \mathrm{SD}$ & 1.20 & 0.86 & 1.56 & 1.32 \\
\hline Median & 1.0 & & 1.0 & \\
\hline
\end{tabular}

Table (3): Comparison between the different studied groups according to GPx.

\begin{tabular}{|c|c|c|c|c|c|}
\hline & $\begin{array}{l}\text { Segmental } \\
(\mathrm{n}=15)\end{array}$ & $\begin{array}{l}\text { Non- } \\
\text { segmental } \\
(n=45)\end{array}$ & $\begin{array}{l}\text { Control } \\
(\mathrm{n}=20)\end{array}$ & $\mathrm{H}$ & $p$ \\
\hline $\begin{array}{l}G P x \\
(m U / m l) \text { : } \\
\text { - Min.- } \\
\text { max. } \\
\text { - Mean } \pm \\
\text { SD } \\
\text { - Median } \\
\text { - Sig. bet. } \\
\text { Grps }\end{array}$ & $\begin{array}{l}6.0-124.0 \\
39.87 \pm 42.6 \\
19.0 \\
p 1=0.199, p\end{array}$ & $\begin{array}{l}6.0-74.0 \\
18.03 \pm 12.40 \\
15.0 \\
2<0.001^{*}, p 3<\end{array}$ & $\begin{array}{l}3.0-50.0 \\
9.45 \pm 10.0 \\
8.0 \\
0.001 *\end{array}$ & $25.464 *$ & $<0.001 *$ \\
\hline $\begin{array}{ll}\mathrm{F}, p & : \mathrm{F} \text { ar } \\
& \text { Pos } \\
\mathrm{H}, p & : \mathrm{H} \mathrm{a} \\
& \mathrm{usin} \\
p_{1} & : p-\mathrm{v} \\
p_{2} & : p-\mathrm{v} \\
p_{*} & : p-\mathrm{v} \\
& : \text { Sta }\end{array}$ & $\begin{array}{l}\text { nd } p \text {-values } \mathrm{fo} \\
\text { t Hoc Test (L } \\
\text { nd } p \text {-values } \mathrm{f} \\
\text { ng Post Hoc T } \\
\text { alue for comp } \\
\text { alue for comp } \\
\text { alue for comp } \\
\text { tistically sign }\end{array}$ & $\begin{array}{l}r \text { ANOVA test } \\
\text { DD). } \\
\text { r Kruskal Wall } \\
\text { est (Dunn's mu } \\
\text { aring between } \\
\text { aring between } \\
\text { aring between } \\
\text { ficant at } p \leq 0 \text {. }\end{array}$ & $\begin{array}{l}\text { Sig. bet. gr } \\
\text { lis test, Sig. } \\
\text { ltiple comp } \\
\text { segmental a } \\
\text { segmental a } \\
\text { non segmen } \\
5 \text {. }\end{array}$ & $\begin{array}{l}\text { rps was do } \\
\text { bet. grps } \\
\text { arisons tes } \\
\text { nd non-seg } \\
\text { and control } \\
\text { tal and co }\end{array}$ & $\begin{array}{l}\text { one using } \\
\text { was done } \\
\text { est). } \\
\text { egmental. } \\
\text { ol. } \\
\text { ontrol. }\end{array}$ \\
\hline
\end{tabular}

Table (4): Correlation between GPx and clinical data in each group.

\begin{tabular}{|c|c|c|c|c|c|c|c|c|}
\hline & \multicolumn{8}{|c|}{ GPx (mU/ml) } \\
\hline & \multicolumn{2}{|c|}{$\begin{array}{c}\text { Total } \\
\text { cases } \\
(n=60)\end{array}$} & \multicolumn{2}{|c|}{$\begin{array}{c}\text { Seg- } \\
\text { mental } \\
(n=15)\end{array}$} & \multicolumn{2}{|c|}{$\begin{array}{l}\text { Non- } \\
\text { segmental } \\
(\mathrm{n}=45)\end{array}$} & \multicolumn{2}{|c|}{$\begin{array}{l}\text { Control } \\
(n=20)\end{array}$} \\
\hline & $r_{\mathrm{s}}$ & $p$ & $r_{\mathrm{s}}$ & $p$ & $r_{\mathrm{s}}$ & $p$ & $r_{\mathrm{s}}$ & $p$ \\
\hline $\begin{array}{l}\cdot \text { Age } \\
\text { (years) }\end{array}$ & 0.058 & 0.660 & 0.238 & 0.393 & 0.051 & 0.741 & -0.217 & 0.357 \\
\hline $\begin{aligned}- & \text { Sex } \\
& \text { (female) }\end{aligned}$ & -0.102 & 0.438 & -0.312 & 0.257 & -0.002 & 0.990 & -0.089 & 0.708 \\
\hline $\begin{array}{l}\cdot \mathrm{BMI} \\
\qquad\left(\mathrm{kg} / \mathrm{m}^{2}\right)\end{array}$ & 0.024 & 0.853 & 0.324 & 0.239 & -0.007 & 0.966 & 0.089 & 0.708 \\
\hline $\begin{array}{l}\text { - Duration } \\
\text { (years) }\end{array}$ & 0.037 & 0.779 & -0.229 & 0.411 & 0.059 & 0.700 & & \\
\hline - Stability & 0.175 & 0.180 & 0.282 & 0.309 & 0.108 & 0.481 & & \\
\hline $\begin{array}{l}\text { Family } \\
\text { history }\end{array}$ & -0.243 & 0.061 & -0.229 & 0.412 & -0.235 & 0.121 & & - \\
\hline - VASI (\%) & -0.174 & 0.182 & -0.384 & 0.157 & -0.106 & 0.487 & & - \\
\hline • VIDA & 0.077 & 0.558 & 0.174 & 0.534 & 0.115 & 0.452 & & - \\
\hline
\end{tabular}

$r_{\mathrm{s}}$ : Spearman coefficient.

: Statistically significant at $p \leq 0.05$.

Table (5): Relation between activity and GPx in each group.

\begin{tabular}{|c|c|c|c|c|}
\hline & \multicolumn{4}{|c|}{ Activity } \\
\hline & \multicolumn{2}{|c|}{ Segmental $(n=15)$} & \multicolumn{2}{|c|}{ Non-segmental $(n=45)$} \\
\hline & $\begin{array}{l}\text { Active } \\
(n=11)\end{array}$ & $\begin{array}{r}\text { Stable } \\
(\mathrm{n}=4)\end{array}$ & $\begin{array}{l}\text { Active } \\
(n=32)\end{array}$ & $\begin{array}{l}\text { Stable } \\
(n=13)\end{array}$ \\
\hline \multicolumn{5}{|l|}{ GPx (m U/m l): } \\
\hline Min.-max. & $6.0-88.0$ & $17.0-124.0$ & $6.0-40.0$ & $10.0-74.0$ \\
\hline Mean \pm SD. & $28.73 \pm 29.91$ & $70.50 \pm 61.78$ & $15.73 \pm 7.08$ & $23.68 \pm 19.63$ \\
\hline Median & 19.02 & 70.50 & 15.0 & 15.0 \\
\hline $\mathrm{U}(p)$ & \multicolumn{2}{|c|}{$14.00(0.292)$} & \multicolumn{2}{|c|}{$179.50(0.474)$} \\
\hline
\end{tabular}

$t, p: t$ and $p$-values for Student $t$-test.

$\mathrm{U}, p: \mathrm{U}$ and $p$-values for Mann Whitney test.

: Statistically significant at $p \leq 0.05$. 


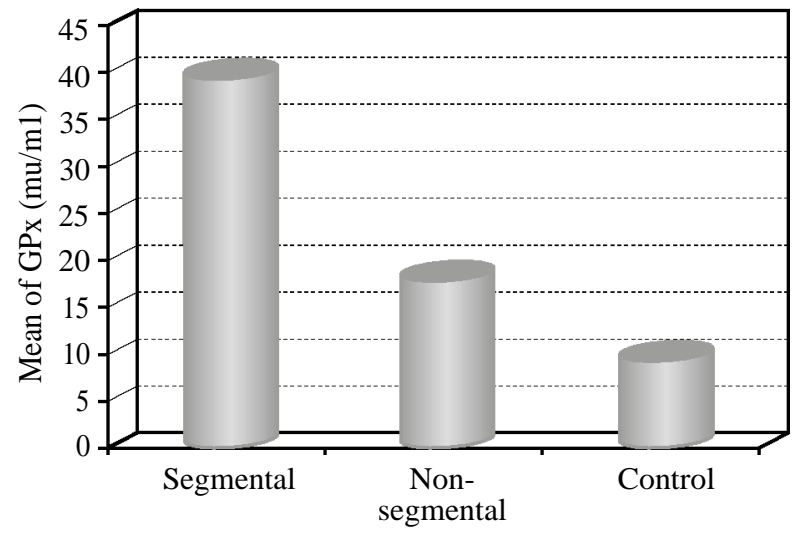

Fig. (1): Comparison between the different studied groups according to GPx.

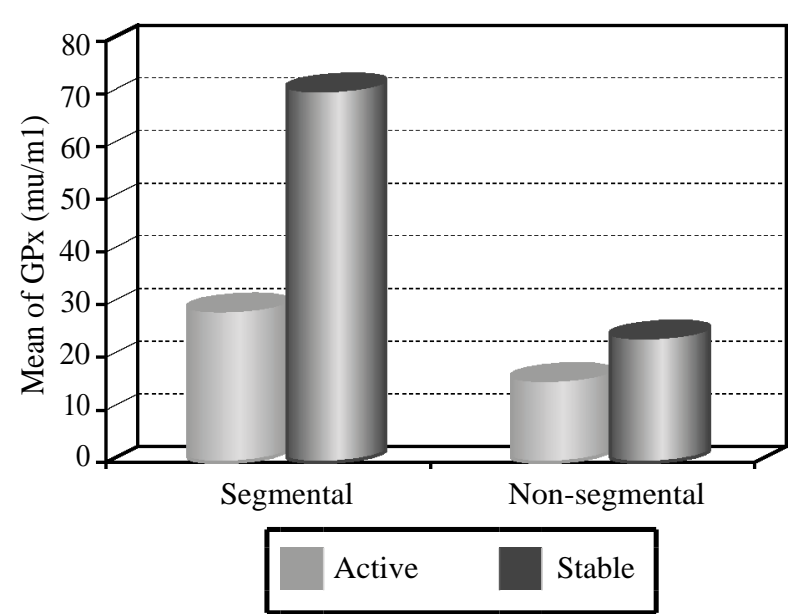

Fig. (2): Relation between activity and GPx (mU/ml) in each group.

\section{Discussion}

Vitiligo is an acquired disease of pigmentation in which epidermal melanocytes are absent. It involves mostly the skin and occasionally the mucosa and hair. Oxidative stress has a big role in the pathogenesis of vitiligo. Glutathione Peroxidases (GPx) are important antioxidant enzymes that defend against oxidative stress [10].

As regards serum activity level of Glutathione peroxidase, our study showed a statistically significant increase in serum activity level of Glutathione peroxidase in vitiligo patients both segmental and non-segmental groups than the control group.

By reviewing literature, we have found wide controversial variations in the studies which measured GPx activity.

In agreement with our study, Kamel et al., [11] and Ozturk et al., [12] revealed, an increase in the level of GPx in plasma of vitiligo patients compared to control group. Kamel et al., explained this increase in order to face the increased level of ROS (hydrogen peroxide and lipid peroxide) that has been produced in vitiligo. Ozturk et al., explained their results by lysis of erythrocytes due to increased ROS level in erythrocytes releasing its GPx in plasma increasing plasma GPx level.

Contrary to our results, Zedan et al., [13], Jalel and Hamdaoui [14] and Khan et al., [15] showed a statistically significant decrease in serum GPx activity level in the patients with vitiligo compared to the healthy controls. They explained their results that the low GPx levels in patients with vitiligo may be due to its consumption in neutralizing the increasing levels of the free radicals as GPx not only degrades hydrogen peroxide but also has the ability to neutralize lipid hydroperoxides [16].

Other studies showed that there were no statistically significant differences between serum levels of GPx activity in vitiligo and controls as in the studies conducted by, Barikbin et al., [17] and Batçiog lu et al., [18]. They explained their results that melanocyte damage in vitiligo is probably linked to mechanisms other than a disturbance in GPx activity.

Measurement of GPx activity level has shown wide controversies and big contrast. This contrast may be due to different methodologies used for analysis of GPx activity. The complex interaction of biochemical, environmental, and immunologic events, may account for these contrasting results [13].

Some studies examined its plasma level, other studies examined GPx activity in erythrocytes. Several studies showed decreased its activity in erythrocytes like those conducted by (Metta et al., [19]; Ines et al., [4] ; Karsli et al., [20] and Dammak et al., [21]. However, another study conducted by Hazneciet et al., [7] didn't find any difference between the erythrocyte GPx levels among the vitiligo patients and healthy controls.

Moreover, epidermal level of Gpx was measured by Kamel et al., [11] and Yildirim et al., [5] revealed an increase in level of GPx in skin of vitiligo patients than the control group and this was in contrast to Passi et al., [22] in which their study on active vitiligo patients revealed decreased epidermal activity of GPx compared to control group.

In our study, the correlations between serum activity level of GPx and clinical data including (activity, age, sex, duration, VASI, VIDA) and lipid profile in each group were statistically nonsignificant similar to Zedan et al., [13] who found that the correlations between GPx activity level 
and the clinical features were statistically nonsignificant although their results showed statistically significant decrease in GPx activity level.

\section{Conclusion:}

Oxidative stress is thought to play a significant role in the pathogenesis of vitiligo through imbalance of oxidant-antioxidant systems including significantly increased GPx activity level in vitiligo patients compared to control group in the present study. So antioxidants may have a role in the treatment of vitiligo.

\section{References}

1- PASSERON T. and ORTONNE J.P.: Vitiligo and other disorders of hypopigmentation. In: Bolognia JL, Schaffer JV, Duncan KO and Ko CJ (eds). Bolognia textbook of dermatology 4th ed., Elsevier., P: 1090-2, 2018.

2- LEE H., LEE M.H., LEE D.Y., KANG H.Y., KIM K.H., CHOI G.S., et al.: Pre valence of vitiligo and associated comorbidities in Korea. Yonsei Med. J., 56 (3): 719-25, 2015.

3- GUERRA L., DELLAMBRA E., BRESCIA S. and RASKOVIC D.: Vitiligo: Pathogenetic hypotheses and targets for current therapies. Curr. Drug. Metab., 11 (5): 451-67, 2010.

4- INES D., SONIA B., RIADH B.M., SLAHEDDINE M., HAMIDA T., HAMADI A., et al.: A comparative study of oxidant-antioxidant status in stable and active vitiligo patients. Arch. Dermatol. Res., 298 (4): 147-52, 2006.

5- YILDIRIM M., BAYSAL V., INALOZ H.S. and CAN M.: The role of oxidants and antioxidants in generalized vitiligo at tissue level. J. Eur. Acad. Dermatol. Venereol., 18 (6): 683-6, 2004.

6- KOCA R., ARMUTCU F., ALTINYAZAR H.C. and GÜREL A.: Oxidant-antioxidant enzymes and lipid peroxidation in generalized vitiligo. Clin. Exp. Dermatol., 29 (4): 406-9, 2004.

7- HAZNECI E., KARABULUT A.B., ÖZTÜRK Ç., BATÇIOGLU K., DOGAN G., KARACA S ., et al.: A comparative study of superoxide dismutase, catalase, and glutathione peroxidase activities and nitrate levels in vitiligo patients. Int. J. Dermatol., 44 (8): 636-40, 2005.

8- TOPPO S., FLOHÉ L., URSINI F., VANIN S. and MAIORINO M.: Catalytic mechanisms and specificities of glutathione peroxidases: Variations of a basic scheme. Biochimica Biophysica Acta., 1790 (11): 1486-500, 2009.

9- BRIGELIUS-FLOHÉ R. and MAIORINO M.: Glutathione peroxidases. Biochimica Biophysica Acta., 1830 (5): 3289-303, 2013.

10- KARADAG A.S., TUTAL E. and ERTUGRUL D.T. Insulin resistance is increased in patients with vitiligo. Acta. Derm. Venereol., 91 (5): 541-4, 2011.
11- KAMEL N., SOBHY N., KAMAL H. and ISMAIL M. A comparative study of oxidant-antioxidant status in blood and tissue in vitiligo patients. Egypt Dermatol. Online J., 6 (2): 1,2010

12- OZTURK I.C., BATCIOGLU K., KARATAS F., HAZNECI E. and GENC M.: Comparison of plasma malondialdehyde, glutathione, glutathione peroxidase, hydroxyproline and selenium levels in patients with vitiligo and healthy controls. Indian J. Dermatol. Venereol. Leprol., 53 (3): 106, 2008.

13- ZEDAN H., ABD EL-MOTALEB A.A., KASSEM N.M.A., HAFEEZ H.A.A. and HUSSEIN M.R.A.: Low glutathione peroxidase activity levels in patients with vitiligo. J. Cutan. Med. Surg., 19 (2): 144-8, 2015.

14- JALEL A. and HAMDAOUI M.H.: Study of total antioxidant status and glutathione peroxidase activity in Tunisian vitiligo patients. Indian J. Dermatol. Venereol. Leprol., 54 (1): 13, 2009.

15- KHAN R., SATYAM A., GUPTA S., SHARMA V.K. and SHARMA A.: Circulatory levels of antioxidants and lipid peroxidation in Indian patients with generalized and localized vitiligo. Arch. Dermatol. Res., 301 (10): 7317, 2009.

16- AGRAWAL D., SHAJIL E.M., MARFATIA Y.S. and BEGUM R.: Study on the antioxidant status of vitiligo patients of different age groups in Baroda. Pigment. Cell. Res., 17 (3): 289-94, 2004.

17- BARIKBIN B., KAVAND S., YOUSEFI M., HEDAYATI M. and SAEEDI M.: No differences in serum selenium levels and blood glutathione peroxidase activities in patients with vitiligo compared with healthy control subjects. J. Am. Acad. Dermatol., 64 (2): 444-5, 2011.

18- BATÇIOGLU K., HAZNECı E., ÖZTÜRK Ç., KARABULUT A.B. and KARADAG N.: The skin and plasma antioxidant enzyme activities in patients with vitiligo.Trakya Üniversitesi Tıp Fakültesi Dergisi, 27 (4): 3547,2010.

19- METTA A.K., METTA S., KAZMI I. and RAJ G.: Evaluation of oxidative stress and lipid profile in patients of generalized vitiligo. Int. J. Med. Sci. Public Health, 5 (3): 493-6, 2016.

20- KARSLI N., AKCALI C., OZGOZTASI O., KIRTAK N. and INALOZ S.: Role of oxidative stress in the pathogenesis of vitiligo with special emphasis on the antioxidant action of narrow band ultraviolet B phototherapy. J. Int. Med. Res., 42 (3): 799-805, 2014.

21- DAMMAK I., BOUDAYA S., BEN ABDALLAH F., TURKI H., ATTIA H. and HENTATI B.: Antioxidant enzymes and lipid peroxidation at the tissue level in patients with stable and active vitiligo. Int. J. Dermatol., 48 (5): 476-80, 2009.

22- PASSI S., GRANDINETTI M., MAGGIO F., STANCATO A. and De LUCA C.: Epidermal oxidative stress in vitiligo. Pigment. Cell. Res., 11 (2): 81-5, 1998. 


\section{تقييم مستوى الجلوتاثيون بيروكسيديز فى مصل مرضى البهاق}

يعد مرض البهاق أضطراب جلدى مكتسب يتميز بوجود بقع محددة ناقصة الصبغة تصيب الجلد والثعر والأغثية المخاطية. بالرغم من

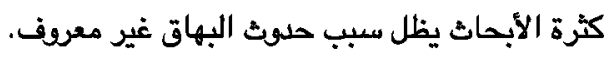

الهدف من الدراسة هو قياس مستوى نشاط الجلوتاثيون بيروكسيديز فى مصل مرضى البهاق لتقييم دوره فى المرضى وعلاقته بتطور المرض ونثاطه.

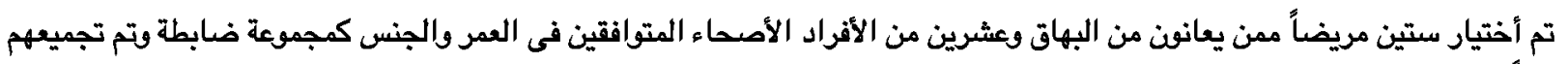

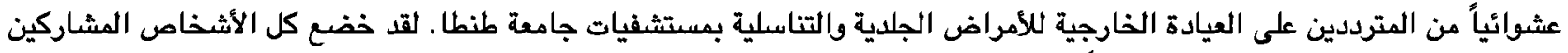

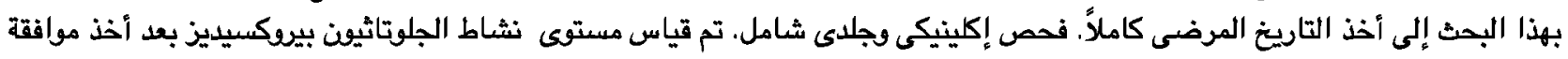
كتابية من المشاركين.

نتائج البحث: وجدت زيادة ذات دلالة إحصائية في مستوى نثاط أنزيم الجلوتاثيون بيروكسيديز فى مصل مرضى البهاق القطعى وغير القطعى عنه فى المجموعة الضـابطة ولكن لم تلاحظ علاقة ذات دلالة إحصائية بينه وبين (مستوى دهون، البيانات الإكلينيكية). الأستنتاج من هذه الدراسة أنه من المحتمل حدوث مرض البهاق بواسطة عملية الإجهاد التاكسدى ممثلاً هذا بزيادة نشاط أنزيم الجلوتاثينف بيركسيديز في الدراسة الحالية. 